Jurnal Kesehatan Islam

e-ISSN : 2615-8345

Publkasi oleh Fakults Kedokteran, Universitas Islam Malang

Pages: $1-8$

Email : jkesislam@unisma.ac.id

Home Page : http://riset.unisma.ac.id/index.php/jki

\title{
Gambaran Kompetensi Kognitif Mahasiswa Profesi Dokter di Rumah Sakit Pendidikan FK UNISMA
}

\author{
Dewi AR*, Anisa R* \\ Fakultas Kedokteran, Universitas Islam Malang \\ Email: dr_ariani_rd@yahoo.com \\ Abstrak
}

Latar Belakang. Kompetensi kognitif mahasiswa profesi dokter di Indonesia dievaluasi melalui Uji Kompetensi Mahasiswa Program studi Profesi Dokter (UKMPPD) secara nasional yang merupakan exit exam dalam pendidikan kedokteran Indonesia.

Tujuan. Penelitian deskriptif ini bertujuan untuk mengevaluasi kompetensi kognitif mahasiswa program studi profesi dokter FK UNISMA sebagai persiapan untuk menghadapi UKMPPD melalui progress test.

Metode. Jenis penelitian deskriptif dengan menampilkan data hasil progress test berdasarkan laboratorium yaitu ilmu penyakit dalam (IPD), bedah, neurologi dan mata dari empat rumah sakit pendidikan yang berbeda. Data ditampilkan dalam mean \pm SD skor progress test.

Hasil. Hasil progress test untuk soal IPD, mahasiswa yang menempuh kepaniteraannya di RS Syamrabu Bangkalan, RS Mardi Waluyo Blitar, RS Kanjuruhan Kepanjen, dan di RS Blambangan Banyuwangi yaitu $57,47 \pm 9,31 ; 53,26 \pm 7,77 ; 50,21 \pm 7,85$; dan 57,38 $\pm 6,74$. Untuk soal Ilmu Bedah, mahasiswa yang menempuh kepaniteraannya di RS Syamrabu Bangkalan, RS Mardi Waluyo Blitar, RS Kanjuruhan Kepanjen, dan di RS

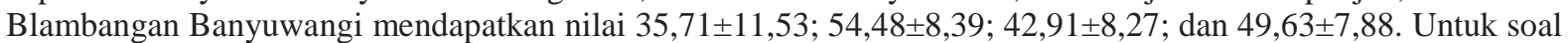
Ilmu Neurologi, mahasiswa yang menempuh kepaniteraannya di RS Syamrabu Bangkalan, RS Mardi Waluyo Blitar, RS Kanjuruhan Kepanjen, dan di RS Blambangan Banyuwangi mendapatkan nilai 54,82 $\pm 8,03$; $52,71 \pm 9,73 ; 45,29 \pm 7,54$; dan 54,51 $\pm 8,28$. Untuk soal Ilmu Kesehatan Mata, mahasiswa yang menempuh kepaniteraannya di RS Syamrabu Bangkalan, RS Mardi Waluyo Blitar, RS Kanjuruhan Kepanjen, dan di RS

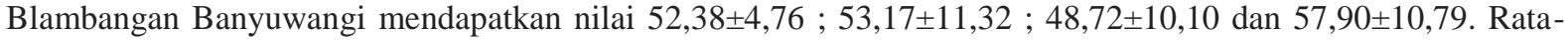
rata nilai progress test dari keempat bidang tersebut (IPD, Bedah, Neurologi, dan Mata) di RS Syamrabu Bangkalan, RS Mardi Waluyo Blitar, RS Kanjuruhan Kepanjen, dan di RS Blambangan Banyuwangi didapatkan 50,$10 ; 53,41 ; 46,78$; dan 54,86.

Kesimpulan. Hasil progress test mahasiswa program studi profesi dokter FK UNISMA semester gasal. TA 2018-19 untuk soal bidang ilmu penyakit dalam, ilmu bedah, ilmu neurologi dan ilmu kesehatan mata masih belum mencapai nilai batas lulus UKMPPD.

Kata kunci: kompetensi kognitif, progress test, rumah sakit pendidikan, ujian nasional.

\section{PENDAHULUAN}

Universitas Islam Malang memiliki Program Studi Profesi Dokter sejak 2010. Pada Uji Kompetensi Mahasiswa Program studi Profesi Dokter (UKMPPD), mahasiswa profesi dokter dari UNISMA memiliki tingkat kelulusan sekitar 100\% hingga $70 \%$. Sejak gelombang pertama, dalam rangka mempersiapkan dokter muda untuk ujian nasional, Fakultas Kedokteran
UNISMA mengatur kelompok studi yang terdiri dari pakar dan mentor sebaya, wajib untuk setiap dokter muda yang telah melewati semua rotasi klinis mereka. Demi pendidikan profesional yang lebih baik, tanggung jawab mempersiapkan dokter muda untuk ujian nasional ini selanjutnya akan dipikul oleh rumah sakit pendidikan, laboratorium / departemen dan klinisi sebagai pendidik. Sebelumnya, suatu survey deskriptif analitik oleh 
Firmansyah $^{1}$, telah dilakukan untuk menganalisis pengalaman klinik dan peran dosen pembimbing klinik di RS Pendidikan FK UNISMA.

Progress test sebagai alat penilaian biasanya diberikan kepada semua mahasiswa kedokteran pada waktu yang sama dan secara berkala dua hingga empat kali setahun sepanjang seluruh program akademik. Tes ini menilai kompetensi kognitif lengkap terlepas dari tingkat tahun peserta. Untuk mahasiswa kedokteran, hasil progress test menunjukkan seberapa banyak pengetahuan dan pemahaman mereka tentang kedokteran berkembang dan seberapa efektif gaya dan kebiasaan belajar mereka. Untuk Fakultas Kedokteran, hasil progress test dapat digunakan sebagai ukuran jaminan kualitas apakah program sudah memenuhi tujuan kurikulumnya. $^{2}$ Progress test yang dilaporkan dalam makalah ini bertujuan untuk menilai bagaimana laboratorium dan rumah sakit pendidikan yang bekerja sama dengan Fakultas Kedokteran UNISMA dapat memenuhi tujuannya dalam mempersiapkan mahasiswa program studi profesi dokter untuk ujian nasional mereka.

\section{METODE}

Progress test dirancang oleh Medical Education Unit Fakultas Kedokteran UNISMA. Pertanyaan untuk tes tersebut diperoleh dari soal try out UKMPPD yang telah direview oleh Asosiasi Institusi Pendidikan Kedokteran Indonesia (AIPKI) wilayah V. Sebelum setiap batch ujian nasional, setiap anggota mengumpulkan pertanyaan sesuai permintaan koordinator regional melalui item bank analyzer institusi dan kemudian pertemuan review soal diadakan. Dalam pertemuan ini reviewer dari masing-masing bidang spesialisasi memeriksa pertanyaan yang diajukan sesuai dengan keahlian mereka. Pertanyaan yang dikoreksi dan diterima kemudian diajukan oleh koordinator wilayah kepada koordinator ujian nasional. Soal yang tidak digunakan oleh koordinator nasional kemudian didistribusikan ke setiap fakultas kedokteran di wilayah V sebagai soal try out. Pertanyaan-pertanyaan tersebut memenuhi tujuh aspek ujian nasional yaitu bidang kompetensi, jenis pengetahuan, proses kognitif, mekanisme penyakit, sistem organ, proses klinis, dan orientasi.

Ada 200 pertanyaan pilihan ganda 5 pilihan, menggunakan perangkat lunak siPENA yang dikembangkan oleh Panitia Nasional UKMPPD dalam 200 menit. Fasilitas computer based test di Fakultas Kedokteran UNISMA terdiri dari 70 personal computer, dan dengan total 135 mahasiswa profesi dokter maka tes dilakukan dalam tiga sesi. Sesi diadakan dua kali secara simultan dan yang terakhir di hari berikutnya, di awal semester pertama di tahun akademik 2018/2019 ini.

Skor dihitung berdasarkan jumlah total jawaban yang benar, tanpa penalti untuk jawaban salah. Karena tujuan formatif dari progress test ini, metode standard setting untuk menentukan cut off lulus / gagal tidak diadakan. Semua peserta menyadari bahwa nilai cut off ujian nasional adalah 66 atau 68. Lembar hasil memberikan perincian untuk setiap aspek dan bidang ilmu. Hasil progress test kemudian disajikan berdasarkan bidang ilmu (laboratorium) dan rumah sakit pendidikan.

\section{HASIL}

Seluruh 135 mahasiswa profesi kedokteran hadir dalam tes ini. Nilai ratarata adalah 52,19 dengan skor tertinggi adalah 69 dan skor terendah 35 .

Hasil progress test untuk soal Ilmu

Penyakit Dalam, rata-rata terbaik didapatkan oleh mahasiswa profesi dokter yang menempuh kepaniteraannya di RS Syamrabu Bangkalan (43 orang) dengan 


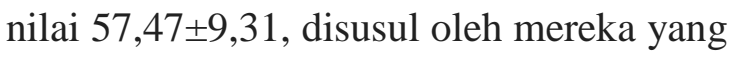
menempuh kepaniteraan klinik madya laboratorium Ilmu Penyakit Dalamnya di RS Blambangan Banyuwangi (25 orang) $57,38 \pm 6,74$, kemudian di RS Mardi Waluyo Blitar (30 orang) 53,26 $\pm 7,77$ dan terendah dari mahasiswa yang menempuh kepaniteraan IPD di RS Kanjuruhan Kepanjen 50,21 17,85 .

Untuk soal Ilmu Bedah, mahasiswa profesi dokter yang menempuh kepaniteraannya di RS Mardi Waluyo Blitar (30 orang) mendapatkan rata-rata tertinggi yaitu $54,48 \pm 8,39$, disusul mahasiswa dari RS Blambangan Banyuwangi (25 orang) dengan rata-rata 49,63 $\pm 7,88$, kemudian RS Kanjuruhan

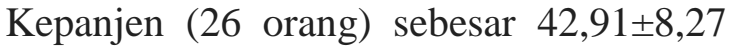
dan terakhir RS Syamrabu Bangkalan (7 orang) mendapatkan nilai 35,71 111,53 .

Untuk soal Ilmu Neurologi, rata-rata terbaik didapatkan oleh mahasiswa profesi dokter yang menempuh kepaniteraannya di RS Syamrabu Bangkalan (32 orang) dengan nilai $54,82 \pm 8,03$, kemudian di $\mathrm{RS}$ Blambangan Banyuwangi (25 orang) $54,51 \pm 8,28$, disusul oleh mereka yang menempuh kepaniteraannya di RS Mardi Waluyo Blitar (25 orang) 52,71 $\pm 9,73$ dan terendah mahasiswa dari RS Kanjuruhan Kepanjen (27 orang) dengan rata-rata

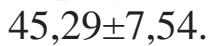

Untuk soal Ilmu Kesehatan Mata, mahasiswa profesi dokter yang menempuh kepaniteraannya di RS Blambangan Banyuwangi (25 orang) mendapatkan ratarata nilai terbaik yaitu sebesar 57,90 $\pm 10,79$, kemudian RS Mardi Waluyo Blitar (30 orang) 53,17 $\pm 11,32$, disusul RS Syamrabu Bangkalan (3 orang) sebesar $52,38 \pm 4,76$ dan dari RS Kanjuruhan Kepanjen (26 orang) 48,72 $\pm 10,10$.

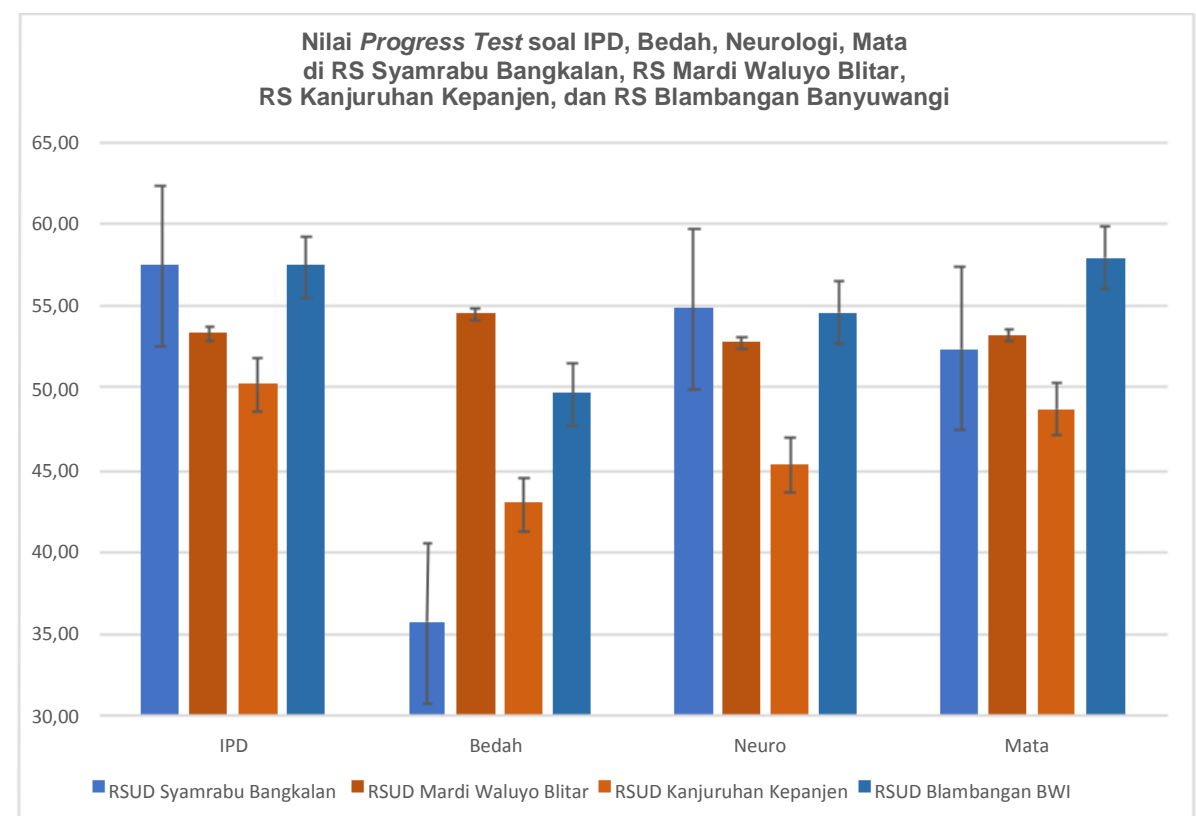

Grafik 1. Nilai Progress Test soal IPD, Bedah, Neurologi dan Mata dari mahasiswa yang menempuh kepaniteraan klinik IPD, Bedah, Neurologi dan Mata di RS Syamrabu Bangkalan, RS Mardi Waluyo Blitar, RS Kanjuruhan Kepanjen dan RS Blambangan Banyuwangi.

Tabel 1. Rata-rata Nilai Progress Test masing-masing Rumah Sakit 


\begin{tabular}{lc}
\hline \multicolumn{1}{c}{ Rumah Sakit } & $\begin{array}{c}\text { Nilai Progress Test } \\
\text { (soal IPD, Bedah, Neuro, Mata) }\end{array}$ \\
\hline RS Syamrabu Bangkalan & 50,10 \\
RS Mardi Waluyo Blitar & 53,41 \\
RS Kanjuruhan Kepanjen & 46,78 \\
RS Blambangan Banyuwangi & 54,86 \\
\hline
\end{tabular}

Rata-rata nilai progress test dari keempat bidang tersebut (Ilmu Penyakit Dalam, Bedah, Neurologi, dan Mata) yang terbaik didapatkan dari mahasiswa yang menempuh kepaniteraan Ilmu Penyakit Dalam / Bedah / Neurologi maupun Mata di RS Blambangan Banyuwangi sebesar 54,86, disusul dari RS Mardi Waluyo Blitar dengan rata-rata 53,41, kemudian RS Syamrabu Bangkalan didapatkan 50,10 dan di RS Kanjuruhan Kepanjen 46,78.

\section{DISKUSI}

Sejak diperkenalkannya progress test pengetahuan kedokteran pada akhir 1970an di Universitas Maastricht dan Universitas Missouri secara independen, alat penilaian longitudinal dengan pertanyaan pilihan ganda ini telah digunakan di sekolah kedokteran di seluruh dunia. Progress test berfungsi sebagai mekanisme umpan balik bagi mahasiswa tentang tingkat pengetahuan dan pertumbuhan mereka, dan untuk fakultas kedokteran sebagai penilaian strategi pembelajaran. $^{2}$

Program studi Profesi Dokter di Fakultas Kedokteran UNISMA terdiri dari 40 SKS di enam belas laboratorium / departemen selama 109 minggu atau empat bulan dan tiga minggu. Ilmu Penyakit Dalam (termasuk Pulmonologi \& Kardiologi), Bedah (termasuk Ortopedi, Urologi dan Bedah Saraf), OBGYN, Pediatri dan Kesehatan Masyarakat adalah laboratorium sepuluh minggu. THT, Mata, Neurologi, Radiologi, Kedokteran Fisik dan Rehabilitas, Psikiatri, Forensik dan
Farmasi adalah laboratorium selama lima minggu, sedangkan Anestesiologi dan Kedokteran Gigi adalah tiga minggu.

Keempat rumah sakit pendidikan melakukan rotasi di empat laboratorium utama, dan sebagian besar yang kecil, kecuali untuk Psikiatri di dr. Rumah Sakit Jiwa Radjiman, Forensik di Rumah Sakit Polisi Bhayangkara. Strategi pembelajaran dalam kepaniteraan klinik termasuk bed side teaching, tutorial klinis, magang / $\mathrm{co}$ assistency, tugas klinik-bangsal rumah sakit dan ruang gawat darurat, jaga malam dan laporan pagi, pembacaan jurnal, tinjauan literatur dan presentasi kasus. Supervisi pada saat co assistency sangat penting dalam proses pembelajaran mahasiswa profesi kedokteran. Di keempat rumah sakit pendidikan, kepaniteraan klinik diselenggarakan dengan memenuhi rasio antara dokter dan mahasiswa sebesar 1: 5 .

Publikasi tentang progress test di Indonesia masih terbatas, terutama yang dilakukan dalam periode klinis. Satu studi yang diterbitkan di Universitas Yarsi $^{3}$ dilakukan pada mahasiswa pre klinik, hanya sampel dan tidak semua mahasiswa, dan menggunakan pertanyaan dari sumber internal bukan ujian nasional, sehingga tidak dapat digunakan sebagai pembanding untuk penelitian ini. Progress test ini adalah yang pertama yang dilakukan di Fakultas Kedokteran UNISMA, namun, peserta sudah terbiasa dengan tes berbasis komputer karena biasanya digunakan dalam tes mingguan atau tes blok pada masa pembelajaran pre klinik. Hasil 
progress test ini menunjukkan skor yang sangat rendah, dengan hanya satu dari 135 mahasiswa profesi kedokteran yang mencapai nilai batas lulus ujian nasional dan sebagian besar peserta hanya bisa memberikan sekitar 50\% jawaban yang benar.

Ferguson et $a l^{4}$ menyatakan dalam literature review tentang faktor-faktor yang terkait dengan keberhasilan di pendidikan kedokteran bahwa kinerja

akademis sebelumnya merupakan prediktor yang baik untuk pencapaian dalam pelatihan medis, demikian pula

faktor-faktor non-kognitif seperti kepribadian dan gaya belajar. Persyaratan mahasiswa baru Program studi Profesi Dokter di FK UNISMA adalah IPK Sarjana Kedokteran minimal 2,50. Lebih jauh lagi, persyaratan pendaftaran mahasiswa baru FK UNISMA (pre klinik) mencakup pula nilai biologi SMA minimal 8 dalam rapot dan minimal 7 dalam ujian nasional sekolah menengah. Ujian masuk Fakultas Kedokteran UNISMA juga terdiri dari tes psikologi yang dapat memberikan data kepribadian dan gaya belajar. Kinerja akademis sebelumnya dalam bentuk IPK pre klinik belum dievaluasi dalam laporan ini, untuk mengetahui faktor yang berpengaruh terhadap hasil progress test dan persiapan UKMPPD, kaitan hasil progress test dengan IPK harus dievaluasi.

Ferguson et al ${ }^{4}$ menyatakan bahwa

faktor-faktor non-kognitif seperti kepribadian dan gaya belajar berpengaruh

terhadap keberhasilan pendidikan kedokteran. Faktor-faktor tersebut belum digali dalam studi ini. Progress test ini bersifat sebagai tes formatif, sehingga dapat diperkirakan sikap mahasiswa dalam mempersiapkan dan mengerjakan tes cenderung santai. Meskipun hal ini baik dalam artian minimalnya upaya untuk menebak, hal ini juga merugikan karena tidak menggambarkan tingkat pengetahuan peserta yang sebenarnya, yang dalam hal ini menjadi tampak lebih rendah. Tes ini juga dilakukan pada akhir siklus rotasi, yang berarti sebagian besar peserta menjalani ujian akhir laboratorium setidaknya selama satu atau dua minggu sebelum progress test. Hal ini memberikan sedikit, hampir tidak ada, waktu untuk belajar untuk progress test, yang menghasilkan skor rendah. Studi oleh Musa dan Haque ${ }^{5}$ di Malaysia menemukan bahwa membaca di tempat dan waktu tertentu mempengaruhi kinerja mahasiswa, sementara Shawwa et $a l^{6}$ menemukan bahwa belajar lebih dari empat jam sehari diperlukan untuk mencapai nilai yang lebih baik. Untuk perbaikan hasil progress test dan meningkatkan kesiapan mahasiswa profesi dokter FK UNISMA menghadapi UKMPPD, perubahan jadwal progress test menjadi pada awal atau pertengahan siklus, serta kuesioner mengenai gaya belajar dan persepsi terhadap tes perlu dilakukan.

McManus et $a l^{7}$ menyatakan bahwa untuk mendapatkan pengetahuan melalui pengalaman klinis diperlukan strategi belajar dan pendalaman yang khusus. Studi oleh Mathers et $a l^{8}$ menemukan bahwa belajar mandiri di lingkungan rumah sakit merupakan permasalahan tersendiri bagi mahasiswa kedokteran. Selama masa pembelajaran pre klinik, mahasiswa terbiasa dengan strategi pembelajaran yang sangat terstruktur dan

didominasi pengajaran. Mahasiswa kedokteran yang memulai rotasi klinis mereka sering merasa sedikit tersesat, tidak tahu apa dan kapan mereka harus

melakukan sesuatu. Belajar dan mendapatkan pengetahuan dari pengalaman klins adalah keterampilan yang sepenuhnya baru dan untuk mendukung para mahasiswa sehingga mereka dapat belajar di rumah sakit McManus et $a l^{4}$ menyarankan periode induksi yang cukup dan buku panduan terstruktur. Periode induksi / pra 
pendidikan di mana dokter muda diperkenalkan kepada semua anggota laboratorium akan memudahkan mereka untuk dekat dengan dosen pembimbing klinis yang diperlukan untuk transfer

pengetahuan dan pada dasarnya memfasilitasi pembelajaran yang efektif. Buku panduan berisi daftar lengkap penyakit dan keterampilan klinis yang harus dikuasasi harus juga dilengkapi dengan di mana dan bagaimana dokter muda akan mendapatkan pengetahuan tentang suatu penyakit atau prosedur diagnostik / perawatan dan sampai seberapa dalam tingkat pemahaman yang harus dipenuhi. Buku panduan dan $\log$ book yang saat ini digunakan di Program Studi Profesi Dokter FK UNISMA memuat kompetensi yang tercantum dalam Standar Kompetensi Dokter Indonesia (SKDI) 2013 sesuai dengan laboratorium masing-masing. Penelitian Firmansyah ${ }^{1}$ pada tahun 2017 di Laboratorium Ilmu Bedah pada tiga rumah sakit pendidikan yang bekerja sama dengan FK UNISMA, mendapatkan bahwa paparan mahasiswa terhadap log book cukup rendah. Perbaikan buku panduan dan log book dengan menambahkan teknis bagaimana

kompetensi-kompetensi tersebut didapatkan serta peningkatan penggunaan (paparan) mahasiswa terhadap panduan dan log book tersebut sangat diperlukan.

Rata-rata nilai progress test soal bidang Ilmu Penyakit Dalam, Bedah, Neurologi dan Mata secara keseluruhan (Tabel 1) menunjukkan bahwa pada nilai progress test dari mahasiswa yang menempuh kepaniteraan klinik di RS Blambangan Banyuwangi lebih baik, disusul oleh RS Mardi Waluyo Blitar dan RS Syamrabu, sedangkan nilai progress test dari mahasiwa yang menempuh kepaniteraan kliniknya di RS Kanjuruhan Kepanjen cenderung rendah. RS Kanjuruhan di Kabupaten Malang merupakan rumah sakit pendidikan yang paling awal menerima dokter muda dari FK UNISMA, diikuti oleh Rumah Sakit Umum Mardi Waluyo di Kota Blitar ketika jumlah mahasiswa program studi profesi bertambah dan membutuhkan rumah sakit lain untuk memenuhi rasio 1 dokter: 5 mahasiswa, kemudian Rumah Sakit Umum Blambangan di Kabupaten Banyuwangi dan yang terakhir bergabung tetapi sudah terakreditasi sebagai rumah sakit pendidikan utama untuk Fakultas Kedokteran UNISMA adalah Rumah Sakit Umum Syarifah Ambami Ratu Ebo Bangkalan di Pulau Madura. Meskipun ada beberapa perbedaan dan keunikan dari masing-masing rumah sakit, kepaniteraan klinik yang berlangsung di masing-masing rumah sakit tersebut masih memenuhi standar yang diperlukan dan secara umum serupa. Semua rumah sakit tersebut berakreditasi B, memiliki jumlah dan variasi kasus yang cukup dan didukung oleh dokter yang telah terlatih sebagai pendidik klinis dengan rasio 1: 5 seperti yang diperintahkan oleh Konsil Kedokteran Indonesia.

Satu studi oleh Mathers et $a l^{7}$ di Inggris menemukan bahwa rumah sakit pendidikan yang lebih tua kadang-kadang memiliki semacam "kelelahan" setelah bertahun-tahun pendidikan, dibandingkan dengan rumah sakit pendidikan yang baru dalam pendidikan. Rumah sakit pendidikan yang baru memiliki keunggulan pendidik klinis yang lebih antusias dan lingkungan rumah sakit yang lebih ramah. Karena mengajar adalah hal baru di rumah sakit ini, "kebaruan" tugas ini dapat menghasilkan antusiasme awal yang diwujudkan dalam pemenuhan komitmen mengajar. Perbedaan tersebut juga didapatkan pada penelitian di FK UNISSULA oleh Rahmawatie et al ${ }^{8}$ yang menemukan bahwa di antara 12 rumah sakit yang terafiliasi dengan UNISSULA, meskipun supervisi klinis secara keseluruhan dianggap baik dan tidak 
menunjukkan perbedaan yang signifikan, namun praktik supervisi klinis bervariasi di antara rumah sakit. Penelitian Firmansyah $^{1}$ pada tahun 2017 di Laboratorium Ilmu Bedah pada tiga rumah sakit pendidikan yang bekerja sama dengan FK UNISMA mendapatkan bahwa hubungan antara dosen pendidik klinis dengan mahasiswa cukup baik, meskipun ada kecenderungan bahwa mahasiswa kurang yakin terhadap cara mengajar dosen pendidik klinik di rumah sakit.

Dalam usaha untuk meningkatkan skor progress test dan memastikan bahwa standar yang sama diberlakukan di semua rumah sakit pendidikan, peran rumah sakit pendidikan utama harus ditekankan. Ketua

Komite Koordinasi Pendidikan
(KomKorDik) yang duduk di rumah sakit pendidikan utama harus mengatur kolaborasi dan berbagi best practices

dalam pengawasan klinis melalui pertemuan rutin, webinar, grup pesan seluler, atau sarana komunikasi lainnya. Beberapa laboratorium seperti Pediatri di RS Bangkalan dan Mata di RS Kanjuruhan, mengadakan tes tertulis dengan menggunakan pertanyaan standar ujian nasional, tetapi praktik ini belum diadopsi di laboratorium lain atau rumah sakit pendidikan lainnya. Melalui koordinasi dari Komkordik, diharapkan intervensi pembelajaran yang meningkatkan keterlibatan dokter di rumah

\section{REFERENSI}

1. Firmansyah $\mathrm{M}$. The differences clinical experience of clerkship students in the department of surgery on three teaching hospitals. J. Islamic. Med. Res. 2017; 1:1, 83-95

2. Wrigley W, Vleuten CPM, Freeman A, Muijtjens A. A systemic framework for the progress test: Strengths, constraints and issues: AMEE Guide No. 71. Medical Teacher. 2012; 34: 683-697

3. Mirfat, Yuhernita. Pemanfaatan progress test sebagai tolak ukur keberhasilan belajar mahasiswa. Jurnal Pendidikan Kedokteran Indonesia. 2014; 3:3, 170-6 sakit pendidikan untuk meningkatkan tingkat kelulusan ujian nasional mahasiswa profesi kedokteran di Fakultas Kedokteran UNISMA seperti tes tertulis atau bahkan tes berbasis komputer menggunakan ujian standar ujian nasional di setiap laboratorium, diskusi difokuskan pada pertanyaan tes, menanyakan

pertanyaan UKMPPD sebelum atau sesudah bedside teaching kasus yang

sesuai, singkatnya semua strategi pembelajaran untuk persiapan menghadapi ujian nasional, harus disosialisasikan, dilaksanakan, dan kemudian dievaluasi antara lain dengan progress test di semester berikutnya.

\section{KESIMPULAN}

Hasil progress test mahasiswa program studi profesi dokter FK UNISMA semester gasal. TA 2018-19 untuk soal bidang ilmu penyakit dalam, ilmu bedah, ilmu neurologi dan ilmu kesehatan mata masih belum mencapai nilai batas lulus UKMPPD. Diperlukan studi lebih lanjut dan perbaikan untuk mengembangkan intervensi pembelajaran yang tepat yang akan meningkatkan keterlibatan dokter pendidik klinis di rumah sakit pendidikan untuk meningkatkan tingkat kelulusan ujian nasional mahasiswa program studi profesi dokter di Fakultas Kedokteran UNISMA.

4. Ferguson E, James D, Madeley L. Factors associated with success in medical school: systematic review of the literature. BMJ 2002;324:952-7

5. Musa RM, Haque M. Academic performance of pre-clinical and clinical medical students' of east coast Malaysian peninsula: a cross-sectional and descriptive study that stimulates their life. Journal of Applied Pharmaceutical Science 2017;7 (06):169-75

6. Shawwa LA, Abulaban AA, Abulaban AA, Merdad A, Baghlaf S, Algethami A, et al. Factors potentially influencing academic performance among medical students. Advances in Medical Education and Practice 2015:6 65-75 
7. McManus IC, Richards P, Winder BC, Sproston KA. Clinical experience, performance in final examinations, and learning style in medical students: prospective study. BMJ 1998;316:34550

8. Mathers J, Parry J, Scully E, Popovic C. A comparison of medical students' perceptions of their initial basic clinical training placements in 'new' and established teaching hospitals, Medical Teacher, 2006; 28:3, e80-e89

9. Rahmawatie DA, Rahayu GR, Prihatiningsih TS. Students Perceptions on the quality of clinical supervision among the 12 affiliated hospital of Medical Faculty of UNISSULA. Sains Medika 3(2):135-49 